\title{
DEVELOPMENT OF CAPITAL MARKETS IN BULGARIA, ROMANIA AND SLOVAKIA
}

Krzysztof Kompa, Department of Econometrics and Statistics WULS-SGGW, Warsaw, Poland Dorota Witkowska, Department of Econometrics and Statistics WULS-SGGW, Warsaw, Poland

dx.doi.org/10.18374/EJBR-13-3.12

\begin{abstract}
The Central and Eastern European countries have been undergoing transformation from a centrally planned economy to a market-orientated economic system since the collapse of the communist regimes in the year 1989. Privatization and activation of stock exchanges are ones of main symptoms of transformation. The aim of research is analysis of the development of stock exchanges in Sofia, Bucharest and Bratislava in the years 2000-2009. The analysis is provided for the logarithmic rates of return of main stock indexes quoted in the investigated countries, employing central tendency, dispersion and skewness measures as well as statistical inference. The research is provided for the whole period and for the sub-periods that are distinguished due to the general tendency at capital markets.
\end{abstract}

Keywords: emerging capital markets, stock index, time series analysis 